DOI: 10.35757/SM.2019.72.2.14

KRYZYS NA ŚWIECIE - ŚWIAT W KRYZYSIE

\author{
RYSZARDA FORMUSZEWICZ
}

Ośrodek Studiów Wschodnich

\title{
Niemcy wobec dekady kryzysu 2008-2017 w świetle debat budżetowych w Bundestagu
}

\author{
Germany and the decade of crisis 2008-2017 \\ in the light of Bundestag debates on the budget
}

This article looks at the reaction of Germany to the crisis phenomena that have been emerging since 2008. An attempt was made to characterize the German response on the basis of the analysis of budget debates in the Bundestag from the period in question, whereby the scope of the analysis was limited to the debates devoted to the Chancellery's budget. Formally, they concern a relatively small budget, however, they are the culmination of parliamentary budget debates, taking on the character of a discussion on government policy with evaluation elements. Their aim is to present and consider the priorities of the ruling coalition, to identify key challenges and to work out the responses. The comparison of the course and content of the debates enabled the author to formulate comparative conclusions regarding individual crises by indicating specific as well as common elements of the state's reaction.

Keywords: Germany, Angela Merkel, Eurozone crisis, financial crisis, migration crisis, security crisis

Słowa kluczowe: Niemcy, Angela Merkel, kryzys strefy euro, kryzys finansowy, kryzys migracyjny, kryzys bezpieczeństwa

W poniższym artykule podjęta została próba scharakteryzowania niemieckiej reakcji na występujące kolejno zjawiska kryzysowe na podstawie analizy debat budżetowych toczących się w Bundestagu w latach 2008-2017².

1 Podstawę analizy stanowią badania przeprowadzone w ramach projektu „Zasoby humanistyki dla budowania i doskonalenia zintegrowanego modelu zarządzania państwem w świetle dynamiki kryzysów i zagrożeń. Dialog humanistyki i administracji a wyzwania dla Polski" zrealizowanego ze środków Ministerstwa Nauki i Szkolnictwa Wyższego przez Centrum Europejskie Natolin. 
Uzasadnienie tego podejścia stanowiło założenie, że przebieg i treść dyskusji parlamentarnych o polityce prowadzonej za pośrednictwem budżetu jest źródłem miarodajnych informacji o strategii rządu wobec kryzysu i podejmowanych działaniach. Analiza umożliwiła sformułowanie wniosków porównawczych poprzez wskazanie specyfiki odpowiedzi państwa niemieckiego w przypadku poszczególnych kryzysów, jak i elementów działania wspólnych wobec każdego z nich. Możliwe było też wychwycenie, w jakim zakresie niemieckie podejście do kryzysu ma charakter stały, a w jakim ulega modyfikacji w zależności od rozpatrywanego zjawiska kryzysowego.

Zakres analizy ograniczony został do obrad nad budżetem Urzędu Kanclerskiego (Einzelplan 04) - tzw. debat ogólnych (Generaldebatte). Formalnie dotyczą one budżetu o relatywnie małym wolumenie, ale stanowią główny punkt rozpatrywania jego projektu, przyjmując charakter dyskusji o polityce rządu z elementami oceniającymi. Służą przedstawieniu i rozpatrzeniu priorytetów rządzącej koalicji, wskazaniu kluczowych wyzwań dla niemieckiej polityki oraz określeniu wystosowywanych wobec nich odpowiedzi. Poprzez powiązanie z decyzjami o zagospodarowaniu zasobów publicznych debaty te dostarczają informacji o rzeczywistych opcjach działania państwa. Najwcześniejsze z osiemnastu analizowanych debat (pierwsze i drugie czytanie projektu budżetu z 2008 r. $^{2}$ ) przypadały na późną fazę funkcjonowania pierwszej wielkiej koalicji pod kierownictwem kanclerz Angeli Merkel. Następne dotyczą okresu rządów koalicji chadecko-liberalnej³ oraz

2 Erste Beratung des von der Bundesregierung eingebrachten Entwurfs eines Gesetzes über die Feststellung des Bundeshaushaltsplans für das Haushaltsjahr 2009 (Haushaltsgesetz 2009), Deutscher Bundestag, Stenografischer Bericht, 175. Sitzung, 17 IX 2008, Plenarprotokoll 16/175; Zweite Beratung des von der Bundesregierung eingebrachten Entwurfs eines Gesetzes über die Feststellung des Bundeshaushaltsplans für das Haushaltsjahr 2009 (Haushaltsgesetz 2009), Deutscher Bundestag, Stenografischer Bericht, 189. Sitzung, 26 XI 2008, Plenarprotokoll 16/189 [dalej: BT 2008-189].

3 Erste Beratung des von der Bundesregierung eingebrachten Entwurfs eines Gesetzes über die Feststellung des Bundeshaushaltsplans für das Haushaltsjahr 2010 (Haushaltsgesetz 2010), Deutscher Bundestag, Stenografischer Bericht, 15. Sitzung, 20 I 2010, Plenarprotokoll 17/15 [dalej: BT 2010-15]; Zweite Beratung des von der Bundesregierung eingebrachten Entwurfs eines Gesetzes über die Feststellung des Bundeshaushaltsplans für das Haushaltsjahr 2010 (Haushaltsgesetz 2010), Deutscher Bundestag, Stenografischer Bericht, 30. Sitzung, 17 III 2010, Plenarprotokoll 17/30 [dalej: BT 2010-30]; Erste Beratung des von der Bundesregierung eingebrachten Entwurfs eines Gesetzes über die Feststellung des Bundeshaushaltsplans für das Haushaltsjahr 2011 (Haushaltsgesetz 2011), Deutscher Bundestag, Stenografischer Bericht, 58. Sitzung, 15 IX 2010, Plenarprotokoll 17/58; Zweite Beratung des von der Bundesregierung eingebrachten Entwurfs eines Gesetzes über die Feststellung des Bundeshaushaltsplans für das Haushaltsjahr 2011 (Haushaltsgesetz 2011), Deutscher Bundestag, Stenografischer Bericht, 74. Sitzung, 
kolejnej odsłony wielkiej koalicji po wyborach w 2013 r. ${ }^{4}$ Stosowane w tekście określenia rząd i opozycja każdorazowo odnoszą się do układu sił występującego w poszczególnych kadencjach: szesnastej (2005-2009), siedemnastej (2009-2013) oraz osiemnastej (2013-2017).

Format analizowanych debat odzwierciedla kluczową rolę ośrodka kanclerskiego jako centrum władzy i głównego aktora w formułowaniu politycznej

24 XI 2010, Plenarprotokoll 17/74; Erste Beratung des von der Bundesregierung eingebrachten Entwurfs eines Gesetzes über die Feststellung des Bundeshaushaltsplans für das Haushaltsjahr 2012 (Haushaltsgesetz 2012), Stenografischer Bericht, 123. Sitzung, 7 IX 2011, Plenarprotokoll 17/123 [dalej: BT 2011-123]; Zweite Beratung des von der Bundesregierung eingebrachten Entwurfs eines Gesetzes über die Feststellung des Bundeshaushaltsplans für das Haushaltsjahr 2012 (Haushaltsgesetz 2012), Stenografischer Bericht, 142. Sitzung, 23 XI 2011, Plenarprotokoll 17/142 [dalej: BT 2011-142]; Erste Beratung des von der Bundesregierung eingebrachten Entwurfs eines Gesetzes über die Feststellung des Bundeshaushaltsplans für das Haushaltsjahr 2013 (Haushaltsgesetz 2013), Stenografischer Bericht, 191. Sitzung, 12 IX 2012, Plenarprotokoll 17/191 [dalej: BT 2012-191]; Zweite Beratung des von der Bundesregierung eingebrachten Entwurfs eines Gesetzes über die Feststellung des Bundeshaushaltsplans für das Haushaltsjahr 2013 (Haushaltsgesetz 2013), Deutscher Bundestag, Stenografischer Bericht, 207. Sitzung, 21 XI 2012, Plenarprotokoll 17/207.

4 Erste Beratung des von der Bundesregierung eingebrachten Entwurfs eines Gesetzes über die Feststellung des Bundeshaushaltsplans für das Haushaltsjahr 2014 (Haushaltsgesetz 2014), Deutscher Bundestag, Stenografischer Bericht, 29. Sitzung, 9 IV 2014, Plenarprotokoll 18/29; Zweite Beratung des von der Bundesregierung eingebrachten Entwurfs eines Gesetzes über die Feststellung des Bundeshaushaltsplans für das Haushaltsjahr 2014 (Haushaltsgesetz 2014), Deutscher Bundestag, Stenografischer Bericht, 42. Sitzung, 25 VI 2014, Plenarprotokoll 18/42 [dalej: BT 2014-42]; Erste Beratung des von der Bundesregierung eingebrachten Entwurfs eines Gesetzes über die Feststellung des Bundeshaushaltsplans für das Haushaltsjahr 2015 (Haushaltsgesetz 2015), Deutscher Bundestag, Stenografischer Bericht, 50. Sitzung, 10 IX 2014, Plenarprotokoll 18/50 [dalej: BT 2014-50]; Zweite Beratung des von der Bundesregierung eingebrachten Entwurfs eines Gesetzes über die Feststellung des Bundeshaushaltsplans für das Haushaltsjahr 2015 (Haushaltsgesetz 2015), Deutscher Bundestag, Stenografischer Bericht, 69. Sitzung, 26 XI 2014, Plenarprotokoll 18/69 [dalej: BT 2014-69]; Erste Beratung des von der Bundesregierung eingebrachten Entwurfs eines Gesetzes über die Feststellung des Bundeshaushaltsplans für das Haushaltsjahr 2016 (Haushaltsgesetz 2016), Deutscher Bundestag, Stenografischer Bericht, 120. Sitzung, 9 IX 2015, Plenarprotokoll 18/120 [dalej: BT 2015-120]; Zweite Beratung des von der Bundesregierung eingebrachten Entwurfs eines Gesetzes über die Feststellung des Bundeshaushaltsplans für das Haushaltsjahr 2016 (Haushaltsgesetz 2016), Deutscher Bundestag, Stenografischer Bericht, 139. Sitzung, 25 XI 2015, Plenarprotokoll 18/139 [dalej: BT 2015-139]; Erste Beratung des von der Bundesregierung eingebrachten Entwurfs eines Gesetzes über die Feststellung des Bundeshaushaltsplans für das Haushaltsjahr 2017 (Haushaltsgesetz 2017), Deutscher Bundestag, Stenografischer Bericht, 186. Sitzung, 7 IX 2016, Plenarprotokoll 18/186; Zweite Beratung des von der Bundesregierung eingebrachten Entwurfs eines Gesetzes über die Feststellung des Bundeshaushaltsplans für das Haushaltsjahr 2017 (Haushaltsgesetz 2017), Deutscher Bundestag, Stenografischer Bericht, 202. Sitzung, 23 XI 2016, Plenarprotokoll 18/202 [dalej: BT 2016-202]. 
odpowiedzi na kryzys. Uczestniczyli w nich aktywnie kanclerz, przewodniczący frakcji parlamentarnych oraz inni znaczący politycy. Pod względem tematycznym w najszerszym zakresie debaty poświęcone są kwestiom stanowiącym domenę szefa rządu (Chefsache), w tym zarządzaniu kryzysowemu. Wyjątkowe w skali europejskiej długotrwałe przywództwo Angeli Merkel w zmieniających się konfiguracjach koalicyjnych dodatkowo uprawnia przeprowadzenie analizy porównawczej.

Celem analizy było ustalenie, jaką rolę odgrywał kryzys przy uzasadnianiu decyzji dotyczących polityki budżetowej państwa, które miały mobilizować jego zasoby, jak diagnozowano kryzys i jakie wnioski dla działań państwa formułowano na podstawie tej diagnozy, jaka była relacja między środkami narodowymi a zarządzaniem kryzysowym w ramach UE oraz jak kształtowano strategię wobec kryzysu w zakresie jego rozwiązywania, łagodzenia objawów oraz zapobiegania wystąpieniu podobnych problemów w przyszłości.

\section{Kryzys finansowy i gospodarczy}

Początek kryzysu finansowego w Niemczech wyznacza praktyczne bankructwo IKB Deutsche Industriebank, do którego doszło 30 lipca 2007 r. Wyraźniejszą cezurę stanowi jednak upadek banku Lehman Brothers 15 września 2008 r. W niedzielę 5 października 2008 r. w reakcji na rozprzestrzenianie się na inne państwa kryzysu wywołanego załamaniem systemu finansowego USA kanclerz Angela Merkel i minister finansów Peer Steinbrück wydali wspólne oświadczenie o gwarantowaniu bezpieczeństwa depozytów, by zapobiec utracie zaufania społeczeństwa do systemu bankowego ${ }^{5}$. To posunięcie wytyczyło kierunek niemieckiej odpowiedzi na kryzys jako manifestacji sprawczości państwa, obejmującej także sferę komunikacyjną.

Debaty nad projektami budżetu Urzędu Kanclerskiego odzwierciedlają wywołaną kryzysem finansowym refleksję nad rolą państwa w okolicznościach zawirowań gospodarczych. W typowej dla siebie ascetycznej retoryce kanclerz Merkel wskazywała, że państwo ma obowiązki (BT 2010-15, s. 1259). Peter Struck z SPD zwracał uwagę na dokonujący się renesans państwa w skali światowej, ponieważ „silne, zdolne do działania państwo jest właśnie w czasach globalnych i otwartych rynków XXI w. ważniejsze niż kiedykolwiek". Zgodnie z potrzebami społecznymi musi ono nadawać rynkowi ramy etyczne

5 Szczegółowo zob. P. Steinbrück, Unterm Strich, Hoffmann und Campe, München 2011, s. $209 \mathrm{i} \mathrm{n.}$ 
i prawne (BT 2008-189, s. 20350). Wobec niewystarczająco dyscyplinującego wpływu rynku państwo miało za zadanie ustanawiać reguły i egzekwować je (Ludwig Stiegler (SPD), BT 2008-189, s. 20364). Przewodniczący frakcji chadeckiej Volker Kauder jako zadanie działań państwa wskazywał ochronę miejsc pracy (BT 2008-189, s. 20355). Nawet ze strony liberalnej FDP płynęły zapewnienia o potrzebie silnego państwa, które ustanawia niezbędne prawa i zapewnia ich egzekwowanie. Zgodnie przyjmowano, że skutki kryzysu zarówno pod względem jego zasięgu, jak i siły oddziaływania wymagały reakcji państwa na poziomie egzekutywy i legislatywy. Katalog działań łagodzących rezultaty zawirowań gospodarczych został stosunkowo szybko skonkretyzowany i relatywnie sprawnie wdrożony ${ }^{6}$.

W odniesieniu do sektora finansowego zdecydowaną interwencję państwa uznano za konieczną w przypadku zagrożenia całej gospodarki narodowej oraz sfery społecznej państwa. Dziedzina usług finansowych zdefiniowana została jako dobro publiczne o egzystencjalnym znaczeniu dla gospodarki międzynarodowej, co posłużyło za uzasadnienie szybkiego i szeroko zakrojonego uruchomienia środków publicznych przy maksymalnie skróconym procesie decyzyjnym. Główną rolę w strategii antykryzysowej odegrały środki podjęte na poziomie narodowym, finansowane ze źródeł podatkowych.

Kryzys zdefiniowano jako nadzwyczajne okoliczności uzasadniające sięgnięcie po wyjątkowe środki - także wobec doświadczenia lat trzydziestych XX w. Nadzwyczajny charakter miał najpierw pakiet ratunkowy dla banków, równoznaczny z obciążeniem podatników kosztami sanacji sektora bankowego, a następnie zwrot w polityce budżetowej. Rząd odstąpił od deklarowanego strategicznego celu konsolidacji budżetu; wskutek kryzysu budżet na 2010 r. przewidywał zaciągnięcie zadłużenia netto w rekordowej wysokości ponad 85 mld euro, dług publiczny wzrósł w 2010 r. do 83,2 proc. PKB, a deficyt budżetowy - do 5 proc. PKB. Mimo zarzucenia konserwatywnej polityki budżetowej w kryzysie konsolidacja budżetu nadal miała być traktowana jako priorytet, a niemiecka kultura stabilności miała stać się przykładem dla Europy. Krokiem do realizacji zamierzeń było przyjęcie w 2009 r. tzw. hamulca długu publicznego, oznaczającego wówczas faktyczne ograniczenie władztwa budżetowego parlamentu. Zadłużenie postrzegane było jako ograniczenie zdolności państwa do działania.

6 Przekrojowo na temat podjętych wówczas działań zob. W. Małachowski, Skutki kryzysu $i$ działania antykryzysowe $w$ gospodarce Niemiec, [w:] Państwa narodowe wobec kryzysu ekonomicznego, red. J. Osiński, Oficyna Wydawnicza Szkoły Głównej Handlowej, Warszawa 2010. 
W 2011 r. kanclerz Angela Merkel ogłosiła wypełnienie głównej obietnicy wyborczej - że Niemcy wyjdą z kryzysu silniejsze, niż w niego weszły. Przyznając, że trudności zostały przezwyciężone m.in. dzięki środkom podatkowym, podkreśliła znaczenie tematu redukcji zakumulowanego przez lata zadłużenia w kontekście problemów występujących strefie euro (Merkel, BT 2011-123, s. 14470). Powrót do poziomu przedkryzysowego nastąpił szybciej, niż oczekiwano, co pozwoliło narracji rządowej obsadzić Niemcy w roli lokomotywy wzrostu w Europie.

Niemieccy politycy byli przekonani, że dobra kondycja kraju w czasie, gdy kryzys nadciągnął, pomogła w osiągnięciu celów zarządzania kryzysowego. Jako czynniki sukcesu wskazywane były skonsolidowane finanse państwa, generowanie koniunktury w UE oraz zachowanie - wbrew ogólnym tendencjom bazy przemysłowej i jej modernizacja. Politycy z satysfakcją odnotowywali relatywnie dobrą sytuację Niemiec w porównaniu do innych państw europejskich. Jako szansę postrzegano dołączenie kraju do grona głównych aktorów współpracujących w walce z kryzysem - inaczej niż podczas wielkiego kryzysu lat trzydziestych XX w.

Już na samym początku kryzys zdiagnozowany został jako zjawisko pochodzenia zewnętrznego. Jego przyczyn niemiecki rząd upatrywał w dostępności zbyt taniego pieniądza w Stanach Zjednoczonych, a także w niewystarczającej regulacji rynków finansowych. Naturę zakłócenia funkcjonowania rynków światowych definiowano także jako kryzys eksportu. Po stronie partii opozycyjnych zakłócenie ładu gospodarczego i społecznego przypisywano neoliberalizmowi. Kluczowym środkiem zapobieżenia wystąpieniu analogicznego kryzysu w przyszłości było poddanie regulacji sektora finansowego, o co już od początku 2007 r. Niemcy zabiegały w ramach G7, a następnie na forum G20. Ze społecznej gospodarki rynkowej wywiedziono zasadę, że każdy produkt, każdy aktor i każdy uczestnik rynku finansowego musi podlegać regulacji. Wobec trudności z wypracowaniem rozwiązań w ramach multilateralnych niektóre instrumenty wprowadzone zostały na poziomie narodowym: podatek bankowy, nadzór, ograniczenie krótkiej sprzedaży i ustawa o restrukturyzacji banków. Liczono przy tym, że w ślad za niemieckimi rozwiązaniami podąży legislacja europejska. Trudności z forsowaniem ograniczeń na arenie międzynarodowej służyły też niekiedy jako alibi dla zaniechania określonych regulacji na poziomie narodowym. Ze względu na brak szerszego poparcia dla podatku od transakcji finansowych Niemcy podjęli próbę wprowadzenia go w formule wzmocnionej współpracy w ramach UE. 
Świadomość, że nie da się walczyć ze wszystkimi globalnymi trendami za pomocą środków narodowych, zwiększała znaczenie współpracy w Europie i uzasadniała praktykowanie podejścia na trzech poziomach: narodowym, europejskim i światowym. Na szczególną uwagę zasługuje jednak postrzeganie Unii Europejskiej jako aktora, którego działania mogą osłabić skuteczność krajowych środków naprawczych. W kryzysie finansowym i gospodarczym Niemcy postulowały złagodzenie przepisów unijnych bądź większą elastyczność w ich stosowaniu. Krytykowane przez opozycję powściągliwe stanowisko wobec zarządzania kryzysowego na poziomie UE koalicja przedstawiała jako służące realizacji niemieckich interesów. Za właściwy tryb postępowania uważano połączenie narodowych i europejskich środków przeciwdziałania kryzysowi, zwracając przy tym uwagę na ograniczone możliwości kopiowania niemieckich rozwiązań przez inne państwa ze względu na różnice uwarunkowań (BT 2008-189).

Liczne zastrzeżenia wiązane były z propozycją powołania rządu gospodarczego na poziomie europejskim. Niemieccy politycy obawiali się uszczerbku dla konkurencyjności własnej gospodarki, przymusu porzucenia swoich atutów, przyjęcia za punkt odniesienia słabszych aktorów w miejsce „najszybszego i najlepszego" oraz arbitralnego narzucenia struktur gospodarczych typowych dla innych systemów, co miałoby zaszkodzić małym i średnim przedsiębiorstwom. Odpierano również ataki na niemiecki model gospodarczy oparty na eksporcie. Zastrzeżenia wobec Brukseli formułowane były m.in. w związku z zagrożeniem, jakie negocjacje polityki klimatycznej niosły dla interesów przemysłu motoryzacyjnego, intensywnie wspieranego właśnie na poziomie narodowym (Merkel, BT 2008-189, s. 20337). Oczekiwano także przynajmniej czasowego rozluźnienia przez Komisję Europejską regulacji dotyczących subwencji dla małych i średnich przedsiębiorstw (Merkel, BT 2008-189, s. 20338).

\section{Kryzys strefy euro}

Zaabsorbowane w 2009 r. własnym kalendarzem politycznym (wyborami do Bundestagu 27 września oraz tworzeniem koalicji i zaprzysiężeniem nowego rządu 28 października), a także wciąż skupione na walce z kryzysem gospodarczym Niemcy nie rozpoznały w pełni ryzyka związanego z ujawnieniem 20 października przez premiera Grecji skorygowanych danych na temat wysokości deficytu budżetowego. Powaga sytuacji dostrzeżona została 
właściwie dopiero przy rozprzestrzenieniu się trudności na kolejnych członków strefy euro: Irlandię, Portugalię i Hiszpanię 7 .

Jako przyczyna problemów wzmocnionych przez spekulacje na rynku finansowym od początku wskazywane było długoletnie naruszanie Paktu stabilności $i$ wzrostu. Ocena ta uzupełniona została następnie o szerszą obserwację nierównomiernego występowania w UE solidnych budżetów i wzrostu. Pełną diagnozę kryzysu przedstawiono w 2011 r., za główny problem uznając wysokie zadłużenie poszczególnych państw strefy euro, z zastrzeżeniem, że nie jest ono następstwem wspierania koniunktury podczas międzynarodowego kryzysu finansowego i gospodarczego, ale skutkiem podążania przez dekady za błędną filozofią osiągania wzrostu bez względu na cenę (Merkel, BT 2011-123, s. 14470). Zdefiniowanie sytuacji jako kryzysu zadłużenia publicznego o starszej genezie przypieczętowało przypisanie odpowiedzialności państwom dotkniętym turbulencjami. Później kanclerz Merkel charakteryzowała kryzys także przez pryzmat deficytu zaufania na rynkach finansowych utraconego w wyniku wieloletnich naruszeń Paktu stabilności i wzrostu. Sprawne przeciwdziałanie kryzysowi utrudniło utrzymujące się zbyt długo w koalicji rządzącej przekonanie, że problem dotyczy tylko gospodarek peryferyjnych, zwłaszcza Grecji, a nie państw rdzenia strefy euro. Opozycja natomiast ,najgłębszy kryzys egzystencjalny Unii Europejskiej" wiązała bezpośrednio z następstwami trwającego kryzysu finansowego. W wymiarze wewnątrzpolitycznym koalicja rządząca przez całą siedemnastą kadencję przypisywała współodpowiedzialność za kryzys dawnemu rządowi SPD i Zielonych, zarzucając mu osłabienie Paktu stabilności $i$ wzrostu oraz zgodę na przyjęcie przez Grecję wspólnej waluty.

Zarządzanie kryzysem w strefie euro zdominowane zostało przez dążenie do przeniesienia niemieckich koncepcji stabilności budżetowej na poziom europejski ${ }^{8}$. Własnym rozwiązaniom przypisano walor modelu i przedstawiano je jako warunek zachowania konkurencyjności UE w wymiarze globalnym. W konsekwencji Niemcy preferowały w kryzysie strefy euro rozwiązanie oparte na założeniu one size fits all - odmiennie od przekonania głoszonego przy walce z kryzysem finansowym i gospodarczym. Strategia walki z kryzysem została oparta na założeniach niemieckiej kultury stabilności, prezentowanej jako

7 Zob. D. Schwarzer, Germany's role and strategy in the euro area-determining factors and scenarios, „The Polish Quarterly of International Affairs” 2013, No. 2, s. 62 i n.

8 Przekrojowo na temat działań Niemiec w kryzysie strefy euro zob.: E. Cziomer, Rola Niemiec w kryzysie strefy Euro po 2009 roku, Krakowskie Towarzystwo Edukacyjne, Oficyna Wydawnicza AFM, Kraków 2013; B. Koszel, Rola Niemiec w procesach decyzyjnych Unii Europejskiej w XXI wieku, Uniwersytet im. Adama Mickiewicza w Poznaniu, Wydawnictwo Naukowe Wydziału Nauk Politycznych i Dziennikarstwa, Poznań 2018, s. 247-282. 
konsolidacja zorientowana na wzrost. Dla uzasadnienia tej ścieżki powoływano się m.in. na dobrą kondycję pokryzysową: „Niemcy pozostają kotwicą stabilności i motorem wzrostu w strefie euro i w całej Unii Europejskiej" (Merkel, BT 2014-42, s. 3691). Wsparcie dla państw dotkniętych problemami zostało uzależnione od spełnienia ściśle określonych warunków. Wiarygodność Niemiec jako promotora konserwatywnej polityki budżetowej była jednak osłabiona niedawnym zwalczaniem kryzysu ekonomicznego poprzez zwiększenie zadłużenia publicznego. Siłę perswazji przykładu niemieckiego obniżały też wyjątkowo korzystne uwarunkowania prowadzenia polityki budżetowej.

Nowym elementem, niewystępującym przy kryzysie finansowym i gospodarczym, były wieloaspektowe wyzwania legitymizacyjne. Pole działania rządu wyznaczały z jednej strony narodowe wymogi konstytucyjne dotyczące tradycyjnych uprawnień parlamentu oraz kontroli procesu integracji europejskiej, a z drugiej - układ kompetencji w strefie euro, z zachowanym przez państwa członkowskie władztwem budżetowym. Kontrowersje towarzyszące zarządzaniu kryzysem strefy euro, skala ryzyka dla budżetu i gospodarki oraz obawa przed brakiem akceptacji społecznej nakładały na polityków szczególny obowiązek uzasadniania podejmowanych decyzji. Stopień trudności tego zadania rósł wraz z kolejnymi przejawami zaostrzania się kryzysu. Podczas debat ogólnych częstym tematem była prezentacja motywów przemawiających za obranym kursem w ramach przezwyciężania kryzysu.

Obóz rządzący uzasadniał też swoje działania dążeniem do zachowania stabilności waluty w interesie gospodarki i indywidualnych oszczędzających (cicha polityka socjalna). Zwracano przy tym uwagę, że euro okazało się w zasadzie stabilniejsze od marki i pomogło w przezwyciężeniu kryzysu finansowego. Przypominano, że przy wprowadzeniu wspólnej waluty obiecane zostało utrzymanie stabilności, akcentując przy tym wagę zaufania społecznego: „Ludzie mają także dlatego zaufanie do tego państwa i do tego kraju, ponieważ mają zaufanie do stabilności naszej waluty" (Hans-Peter Friedrich (CDU/ CSU), BT 2010-30, s. 2742). Stabilność pieniądza podnoszono do rangi Magna Charta społecznej gospodarki rynkowej (Rainer Brüderle (FDP), BT 2012-191, s. 22999). Przywoływano także negatywne doświadczenie historyczne związane z ekstremalną inflacją i dwiema reformami walutowymi.

W kolejnych latach zarządzanie kryzysowe uzasadniano jego rzekomą skutecznością, odnotowując wszelkie przejawy poprawy sytuacji w państwach borykających się z problemami. Jednocześnie widoczny wewnątrz koalicji brak konsensu co do taktyki walki z kryzysem skutkował trudnością w prezentowaniu spójnego stanowiska. 
Podczas debat $\mathrm{w}$ wielu kontekstach powracał temat uwspólnotowienia odpowiedzialności za długi państw strefy euro. SPD mówiło o wprowadzaniu opinii publicznej w błąd poprzez dopuszczenie - wskutek zaniechania - możliwości zakupu obligacji na rynku wtórnym przez Europejski Instrument Stabilności Finansowej i Europejski Bank Centralny (EBC). Zarzucano rządowi wprowadzenie tylnymi drzwiami tzw. obligacji Merkel (Merkel-Bonds) poprzez aktywność EBC (Sigmar Gabriel (SPD), BT 2011-142, s. 16912). Chadecy i liberałowie odrzucali euroobligacje we wszelkiej postaci, z kolei SPD skłonne było je zaakceptować przy zapewnieniu ingerencji w wydatki państw korzystających ze wsparcia. Podobnie krytyczny stosunek wyrażano w koalicji wobec propozycji funduszu obsługi starego zadłużenia (Schuldentilgungsfonds). Koronnym argumentem przeciwko wszelkim formom uwspólnotowienia zobowiązań był brak możliwości ingerowania w budżety państw członkowskich (Merkel, BT 2011-123, s. 14471).

Obok kluczowego dla niemieckiej strategii pojęcia unii stabilności $i \mathrm{w}$ debatach używano terminów nacechowanych negatywnie i syntetycznie ujmujących koncepcje uważane za zagrożenie dla niemieckich interesów: unia transferowa, unia zadtużenia, socjalizm odsetkowy, unia inflacyjna.

Eksponowanym w debatach budżetowych motywem była kwestia kosztów ponoszonych przez Niemcy wskutek samego kryzysu oraz - w ocenie opozycji - w wyniku błędów zarządzania kryzysowego koalicji rządzącej, $\mathrm{z}$ trudem utrzymującej na zewnątrz zgodny kurs. Po stronie obozu rządzącego kwestionowanie oficjalnego stanowiska przedstawiane było z kolei jako występowanie przeciwko niemieckim interesom. Opozycja zarzucała rządowi ukrywanie przed społeczeństwem konieczności poniesienia kosztów walki z kryzysem i skali zaciągniętych zobowiązań.

\section{Kryzys bezpieczeństwa}

Postępująca destabilizacja europejskiego sąsiedztwa rozszerzyła kryzysową agendę rządu niemieckiego o kwestie bezpieczeństwa zewnętrznego i wewnętrznego. Inaczej niż w przypadku wcześniejszych zawirowań gospodarczych odpowiedź trzeciego rządu Angeli Merkel na pogarszającą się sytuację bezpieczeństwa europejskiego nie miała charakteru czysto reaktywnego, ale była też realizacją przyjętych założeń programowych ${ }^{9}$. Postulat większego zaangażowania Niemiec na arenie międzynarodowej wyrażony został

9 Przekrojowo na temat działań Niemiec wobec konfliktu rosyjsko-ukraińskiego zob. tamże, s. 314-366. 
przez prezydenta Joachima Gaucka na otwarciu 50 Monachijskiej Konferencji Bezpieczeństwa. Wsparły go analogiczne w wydźwięku wystąpienia ministrów spraw zagranicznych i obrony ${ }^{10}$. Deklarowany poziom ambicji (tzw. konsensus monachijski ${ }^{11}$ ) szybko poddany został weryfikacji w wyniku agresywnych działań Rosji wobec Ukrainy, a następnie ekspansji tzw. Państwa Islamskiego. Wkrótce destabilizacja na Południu zaczęła oddziaływać na bezpieczeństwo wewnętrzne Niemiec - najpierw poprzez zagrożenie terroryzmem międzynarodowym w kraju, a następnie poprzez rosnącą liczbę napływających do UE uchodźców.

Obok kondycji światowej gospodarki do uzasadnienia prowadzonej przez rząd polityki budżetowej wykorzystywano kontekst otoczenia geopolitycznego. W ramach debat budżetowych osiemnastej kadencji Bundestagu najpierw podnoszono konflikt rosyjsko-ukraiński, następnie zajmowano się zaangażowaniem operacyjnym w południowym sąsiedztwie, a po paryskich zamachach w listopadzie 2015 r. - w większym stopniu kwestiami bezpieczeństwa wewnętrznego. Coraz większego znaczenia nabierała jednocześnie kwestia uchodźców i zapobiegania przyczynom masowych migracji. Ostatnia debata budżetowa kadencji odbyła się 23 listopada 2016 r., już w cieniu zwycięstwa Donalda Trumpa w amerykańskich wyborach prezydenckich.

Niemiecka odpowiedź na kryzys bezpieczeństwa europejskiego obejmowała zwiększoną aktywność dyplomatyczną, przejęcie roli lidera w kształtowaniu polityki UE wobec konfliktu rosyjsko-ukraińskiego oraz większe zaangażowanie $\mathrm{w}$ zarządzanie kryzysowe w południowym sąsiedztwie. Wzmożona aktywność dyplomatyczna i zaangażowanie w zarządzanie kryzysowe stanowiły w pierwszej kolejności próbę przeniesienia wzmocnionej podczas kryzysu strefy euro pozycji Berlina w ramach UE na poziom polityki międzynarodowej. W miarę pogarszania się europejskiego środowiska bezpieczeństwa rosło motywacyjne znaczenie bezpośrednich implikacji dla samych Niemiec. Utrzymywała się preferencja dla działań podejmowanych w ramach wielostronnych (np. OBWE, zwłaszcza w kontekście niemieckiego przewodnictwa w 2016 r.) bądź współpracy w wąskim gronie państw (czwórki normandzkiej). Postulowano wzmocnienie współdziałania w polityce obronnej UE w formule stałej współpracy strukturalnej.

10 Reden auf der MSC 2014, „Munich Security Conference” [online, dostęp: 12 XI 2019], dostępny w internecie: <https://www.securityconference.de/aktivitaeten/munichsecurity-conference/munich-security-conference/msc-2014/reden/>.

11 Zob. B. Giegerich, M. Terhalle, The Munich consensus and the purpose of German power, [w:] International security in the $21^{\text {st }}$ century. Germany's international responsibility, ed. J. Bindenagel, M. Herdegen, K. Kaiser, V\&R Unipress, Göttingen 2017, s. 241 i n. 
Mimo napięć wewnętrznych koalicja prezentowała podczas debat budżetowych $\mathrm{z}$ trudem wypracowany kompromis w zakresie odpowiedzi na agresywne działania Rosji. Regularnie przywoływane w dyskusji sankcje gospodarcze UE wobec tego państwa przedstawiane były przez koalicję rządową i Zielonych jako niezbędny element odpowiedzi na złamanie prawa międzynarodowego i destabilizację Ukrainy Wschodniej. Prorosyjska Lewica krytykowała je natomiast jako wyraz błędnego kursu politycznego skutkującego „bezsensowną wojną gospodarczą”, szkodliwego dla niemieckiego społeczeństwa i gospodarki, zwłaszcza we wschodnich krajach federacji.

Rozbieżności między obozem rządowym a opozycją wyraźnie widać było w przypadku aktywności w zarządzaniu kryzysowym w południowym sąsiedztwie $^{12}$. Ambicje większego zaangażowania Niemiec potwierdzone zostały decyzją udzielenia wsparcia siłom zbrojnym regionalnych władz kurdyjskich - jak podkreślano - za zgodą rządu centralnego w Bagdadzie i w ścisłym uzgodnieniu z partnerami międzynarodowymi. Zapewniając szkolenie i dostawy broni dla peszmergów, Niemcy włączyły się w otwarty konflikt zbrojny. Władze w Berlinie uznawały konieczność wojskowej odpowiedzi na zagrożenie ze strony terrorystycznej organizacji tzw. Państwa Islamskiego, deklarując jednocześnie wsparcie dla wypracowania rozwiązań politycznych gwarantujących trwałą stabilizację. Państwo Islamskie zostało uznane wprost za zagrożenie dla bezpieczeństwa Niemiec. Na apel Francji o udzielenie wsparcia na podstawie klauzuli art. 42 ust. 7 TUE zapadła decyzja o zwiększeniu zaangażowania w Mali i przedłużeniu obecności w Afganistanie. Zieloni krytykowali skupienie się na wymiarze wojskowym, zaniedbywanie prewencji i mały udział niemieckich policjantów w misjach ONZ. Partia Lewica sprzeciwiała się zaangażowaniu wojskowemu i protestowała wobec formatu koalicji chętnych oraz braku mandatu ONZ. Jako alternatywę postulowała embargo na eksport uzbrojenia do rejonów objętych kryzysem oraz ograniczenie możliwości finansowania organizacji terrorystycznych. Od 2015 r. w następstwie kryzysu migracyjnego zaangażowanie dyplomatyczne i wojskowe w południowym sąsiedztwie przedstawiane było już jako element przeciwdziałania przyczynom migracji (obok współpracy rozwojowej).

Znamienne jest, że przebieg debat ogólnych w niewielkim tylko stopniu oddawał kontrowersje dotyczące wysokości budżetu Ministerstwa Obrony. Jednocześnie skutki niedoinwestowania Bundeswehry, dotkniętej

12 Szerzej zob. A. Rinke, Deutschlands neue Nachbarn. Die Bundesregierung weitet ihren Blick auf den Krisenbogen um die EU, „Internationale Politik” 2017, Nr. 4, s. 42-48. 
wieloletnimi redukcjami środków budżetowych, były nie tylko przedmiotem uwagi w kręgach specjalistycznych, ale coraz częściej także tematem doniesień medialnych. Toczony wewnątrz koalicji spór o realizację sojuszniczego zobowiązania do zwiększania budżetu obronnego do 2 proc. PKB osłabiał wiarygodność Niemiec w ramach NATO i przekładał się na realne zdolności niemieckich sił zbrojnych.

Strategiczna adaptacja NATO została uwzględniona 10 września 2014 r. w wystąpieniu Angeli Merkel podczas pierwszego czytania projektu budżetu na rok 2015, po szczycie sojuszu w Walii, do którego doszło na początku tego miesiąca. Kanclerz podkreśliła jednocześnie znaczenie zachowania ograniczeń wojskowej obecności NATO na flance wschodniej wywodzonych z Aktu stanowiqcego o podstawach wzajemnych stosunków, wspótpracy i bezpieczeństwa między NATO i Rosją (BT 2014-50, s. 4559). Podobnie argumentował przewodniczący frakcji SPD Thomas Oppermann, wykluczając stałe stacjonowanie sił NATO w Europie Wschodniej i wskazując sankcje jako wystarczającą reakcję na naruszenie przez Władimira Putina ducha tego porozumienia (BT 2014-50, s. 4565). Nawiązując do wystąpienia prezydenta Bronisława Komorowskiego wygłoszonego tego samego dnia w Bundestagu, przekonywał: „Inni przez dekady przejmowali odpowiedzialność za nas Niemców, za nasze bezpieczeństwo. W takim razie jest oczywiste, że teraz również my przejmujemy odpowiedzialność za innych" (BT 2014-50, s. 4565).

Problematyka bezpieczeństwa wewnętrznego zasygnalizowana została w związku z kwestią powracających do domu bojowników Państwa Islamskiego wywodzących się z UE (BT 2014-69). Po paryskich zamachach w listopadzie 2015 r. odpowiedź na zagrożenie terroryzmem islamskim w kraju została już sformułowana konkretnie, zgodnie z oczekiwaniami społecznymi. Objęła deklarację politycznego wsparcia dla organów bezpieczeństwa oraz odzwierciedlone w budżecie wzmocnienie ich personalnie i technicznie (BT 2015-139). W związku z zagrożeniem terrorystycznym postulowano usprawnienie wymiany informacji między służbami. Niemcy zmodyfikowały także swoje stanowisko w zakresie jednolitej ochrony granicy oraz jednolitych rejestrów wjazdów i wyjazdów do strefy Schengen.

Na uwagę zasługują różnice w polityce komunikacyjnej dotyczącej nakładów na zapewnienie bezpieczeństwa w odniesieniu do jego wewnętrznego i zewnętrznego wymiaru. Stosownie do oczekiwań elektoratu niemieccy politycy szczegółowo przedstawiali dane dotyczące wzmocnienia policji i służb mundurowych, co kontrastowało z powściągliwością co do wyjaśniania nakładów przeznaczonych w budżecie obronnym na wyposażenie sił zbrojnych. 
Niemiecka odpowiedź na kryzys bezpieczeństwa ograniczona była przede wszystkim uwarunkowaniami wewnętrznymi - analogicznie do działań podejmowanych wobec kryzysu w strefie euro. Mimo konsensu monachijskiego korzystanie z pełnego spektrum instrumentów na arenie międzynarodowej utrudniało sceptyczne nastawienie opinii publicznej.

\section{Kryzys migracyjny}

Dla Niemiec punktem zwrotnym w kryzysie migracyjnym było przyjęcie uchodźców z Węgier 4 i 5 września 2015 r. oraz odstąpienie od stosowania reguł rozporządzenia dublińskiego ${ }^{13}$. Przeprowadzone 9 września pierwsze czytanie projektu budżetu na 2016 r. zdominowane zostało przez tematykę migracyjną i wykorzystane przez kanclerz do przedstawienia siedmiopunktowego programu odpowiedzi na kryzys (Merkel, BT 2015-120, s. 11612 i nn.). W ostrej fazie kryzysu migracyjnego jesienią $2015 \mathrm{r}$. centralny problem stanowiły wyzwania logistyczne związane z doraźnym zaopatrzeniem migrantów. Zasadniczo jednak priorytetem niemieckiej odpowiedzi na kryzys migracyjny było ograniczenie liczby ubiegających się o azyl poprzez utrudnienie dostępu do terytorium Niemiec, usprawnienie procedur i zaostrzenie regulacji azylowych ${ }^{14}$.

Odpowiedź na kryzys ponownie oparta została na odrzuceniu izolacji i deklarowanej gotowości zaangażowania (na podstawie doświadczenia społecznej gospodarki rynkowej) na rzecz kształtowania globalizacji w ramach współpracy międzynarodowej. Podejście Niemiec do problematyki uchodźców uzasadniane było także zobowiązaniem opartym na argumencie historycznym. Problem reakcji na rosnącą liczbę uchodźców definiowany był jako kwestia nie tylko narodowa czy europejska, ale także globalna. Niemieccy politycy realistycznie oceniali długoterminową perspektywę borykania się z kryzysem migracyjnym i skalę wyzwania. Jak w poprzednich kryzysach wskazywali na siłę Niemiec jako główną przesłankę zdolności do sprostania wyzwaniu.

Nowym elementem w kryzysie migracyjnym był akcent na siłę państwa płynącą z powszechnego zaangażowania społecznego: „W kryzysie greckim

13 Szczegółowa rekonstrukcja wydarzeń z 4 i 5 września: G. Blume i in., Grenzöffnung für Flüchtlinge: Was geschah wirklich?, „Die Zeit”, 18 VIII 2016; R. Alexander, Die Getriebenen. Merkel und die Flüchtlingspolitik: Report aus dem Innern der Macht, Siedler, München 2017 (wydanie polskie: tenże, Angela Merkel i kryzys migracyjny. Dzień po dniu, Teologia Polityczna, Warszawa 2017).

14 Przekrojowo na temat działań Niemiec w kryzysie migracyjnym zob. B. Koszel, Rola..., s. 282-314. 
nauczyliśmy się, jak niezbędna jest funkcjonująca państwowość [Staatswesen]. W kryzysie uchodźczym widzimy teraz, jak nieocenione jest współczujące, aktywne i dobrze zorganizowane społeczeństwo obywatelskie" (Oppermann (SPD), BT 2015-120, s. 11619).

Pod względem systemowym nowością w zarządzaniu kryzysowym były trudności wynikające $\mathrm{z}$ federalnej struktury państwa ${ }^{15}$. Inaczej niż przy kryzysie strefy euro konstytucyjnie uwarunkowane napięcia między egzekutywą a legislatywą (władztwo budżetowe parlamentu) zastąpione zostały przez problemy spowodowane rozłożeniem kompetencji i ciężarów w systemie federalnym. Rzeczywiste koszty realizacji prawa azylowego - regulowanego na poziomie federacji - ponosiły landy i gminy, co wpływało na zróżnicowanie standardów przyjmowania i zaopatrzenia uchodźców. Uwidoczniło się też regionalne zróżnicowanie sprawności struktur administracyjnych. Uznając te okoliczności, już w czerwcu 2015 r. wyzwanie migracyjne zdefiniowano jako zadanie narodowe realizowane we „wspólnocie odpowiedzialności”16.

Systemowe uwarunkowania państwa federacyjnego wykorzystane zostały przez Zielonych, będących zwolennikami najbardziej liberalnego podejścia do masowej migracji. Dzięki układowi sił w Radzie Federacji blokowali oni rządowe inicjatywy ukierunkowane na zaostrzenie prawa azylowego, co wielokrotnie podnoszone było przez przedstawicieli koalicji podczas debat ogólnych.

Bezprecedensowa skala wyzwania logistycznego, integracyjnego i politycznego znalazła odzwierciedlenie w gospodarowaniu środkami budżetowymi. Mobilizacja będących w dyspozycji państwa środków finansowych przedstawiana była jako istotny element odpowiedzi na kryzys. Zdolność Niemiec do aktywowania zasobów finansowych wobec nieprzewidzianych wyzwań wykorzystana została też jednocześnie do uzasadnienia kursu konsolidacji budżetowej.

Wydatki państwa kierowane były zarówno na wymiar wewnętrzny, głównie odciążenie gmin i landów (jak w przypadku kryzysu finansowego i gospodarczego), jak i zewnętrzny, tj. przeciwdziałanie przyczynom migracji (analogicznie do opanowywania turbulencji wspólnej waluty).

15 O roli federacji w polityce imigracyjnej i azylowej zob. też: T. de Maiziere, Regieren. Innenansichten der Politik, Herder, Freiburg im Breisgau 2019, s. 191 i in.

16 Pressekonferenz der Bundeskanzlerin und der Regierungschefinnen und Regierungschefs der Bundesländer, „Die Bundesregierung” [online], 18 VI 2015 [dostęp: 12 XI 2018], dostępny w internecie: <https://www.bundesregierung.de/breg-de/aktuelles/pressekonferenz-der-bundeskanzlerin-und-der-regierungschefinnen-und-regierungschefs-der-bundeslaender-846066>. 
Zwiększone nakłady budżetowe odzwierciedlały docenienie znaczenia polityki integracyjnej. Przeciwdziałanie powstawaniu równoległych społeczności postrzegano także w kategoriach bezpieczeństwa wewnętrznego, ale przebieg debat budżetowych odzwierciedla wąski zakres dyskusji o kwestiach bezpieczeństwa w kontekście kryzysu migracyjnego. Można przyjąć, że obawiano się rozbudzenia niechęci wobec uchodźców, a osłabieniu poczucia bezpieczeństwa starano się zapobiec konkretnymi działaniami na rzecz wzmocnienia policji i innych struktur bezpieczeństwa.

Przy rozważaniach o kształcie budżetu zwracano też uwagę na ryzyko wzmocnienia skrajnej prawicy w przypadku wystąpienia polaryzacji politycznej w kwestii migracji oraz na potrzebę zapewnienia akceptacji społecznej dla przyjmowania uchodźców. Za istotne uważano przeciwdziałanie wrażeniu, jakoby zasoby państwa wykorzystywano do zaspokajania potrzeb migrantów przy jednoczesnym zaniedbywaniu własnych obywateli.

Obok zapewnienia środków na zarządzanie kryzysowe głównym komponentem działań Niemiec było dążenie do ograniczenia liczby osób wnioskujących o azyl w kraju, co uzasadniano potrzebą zapewnienia pomocy prawdziwie potrzebującym (głównie Syryjczykom) i ich sprawnej integracji. Zalecano też uwzględnienie odczuć społecznych co do limitu zdolności przyjmowania i integracji uchodźców.

Na poziomie krajowym osiągnięto ten cel poprzez modyfikację obowiązujących regulacji w formie tzw. dwóch pakietów azylowych. Koalicja zabiegała o rozszerzenie katalogu państw bezpiecznego pochodzenia w rozumieniu przepisów azylowych - najpierw w odniesieniu do Bałkanów Zachodnich, a potem także Afryki Północnej. Podkreślano potrzebę rozróżnienia między migracją zarobkową i uchodźstwem. Politycy chadecji akcentowali ponadto konieczność ograniczenia bądź wyeliminowania niewłaściwych zachęt systemowych dla migrantów (np. socjalnych świadczeń pieniężnych). W debatach ogólnych wypłynął też wątek wprowadzenia górnego limitu przyjmowania uchodźców (tzw. Obergrenze) oraz stref tranzytowych.

Po raz pierwszy w kryzysie migracyjnym pojawiły się wątpliwości, czy państwo niemieckie jest zdolne do realizowania kluczowych zadań, więc $\mathrm{w}$ konsekwencji w ramach zarządzania kryzysowego usiłowano przeciwdziałać wrażeniu niewydolności jego struktur. Zapobiegając utrwaleniu się przekonania, że rząd utracił kontrolę nad sytuacją, akcentowano w debatach problem skuteczności wydalania osób bez prawa pobytu. Kanclerz wprost odnosiła się do problemu społecznej percepcji pozostawania takich ludzi w kraju i podkreślała potrzebę zapewnienia w Niemczech porządku 
i kierowania, zwłaszcza w sytuacji nieprzestrzegania prawa na granicy zewnętrznej UE. Zapewnienie funkcjonowania państwa prawa $\mathrm{w}$ dziedzinie azylu określiła uzasadnionym oczekiwaniem obywateli (Merkel, BT 2016-202 , s. 20171).

W kontekście kryzysu migracyjnego nowym atrybutem państwa stała się w oczach polityków elastyczność. Wyjątkowość sytuacji miała wymagać przemyślenia obowiązujących regulacji, a nawet czasowego zawieszenia stosowania niektórych z nich bądź obniżenia standardów administracyjnych.

Ograniczeniu liczby uchodźców miało też służyć wsparcie udzielane bezpośrednio w regionach konfliktów, znajdujące wyraz w zwiększeniu sum oddanych do dyspozycji resortom spraw zagranicznych i współpracy rozwojowej na zapobieganie kryzysom środkami cywilnymi oraz pomoc humanitarną. Wskazano, że potencjalnie najszybszy efekt przyniesie udzielenie pomocy mieszkańcom obozów dla uchodźców. Opozycja uznała wzrost budżetu w tym zakresie za niewystarczający, wartość pomocy rozwojowej wciąż nie spełniała bowiem referencyjnego wskaźnika 0,7 proc. PKB. Wskazywano także na wspieranie przez rząd wypracowania politycznych rozwiązań konfliktów na Bliskim Wschodzie. Elementem działań na rzecz zapobiegania przyczynom migracji było zaangażowanie Niemiec w zwalczanie Państwa Islamskiego oraz w misję w Afganistanie.

W reakcji na wyzwanie migracyjne dowartościowana została w niemieckiej polityce Afryka ${ }^{17}$. Berlin promował pogłębienie współpracy na rzecz poprawienia warunków życiowych w tym rejonie świata oraz otwarcia legalnych kanałów migracji w ramach Unii Europejskiej, w formule minilateralnej i multilateralnej, m.in. podczas przewodniczenia G20.

Bezpośrednie oddziaływanie kryzysu migracyjnego na Niemcy zdecydowało o zwiększeniu presji na szybkie reagowanie, co znalazło przełożenie na sposób i formę działania na forum UE. Inaczej niż w przypadku kryzysu strefy euro, Niemcy były tym razem zwolennikami szybkich działań, także w sytuacji braku konsensu wśród państw członkowskich.

Ograniczenie liczby napływających do Niemiec migrantów chciano osiągnąć poprzez odzyskanie kontroli nad zewnętrznymi granicami UE. Poza względami bezpieczeństwa i chęcią ustabilizowania sytuacji dążono do powstrzymania procesu renacjonalizacji ochrony granicy $\mathrm{w}$ ramach strefy Schengen, przy czym same Niemcy również skorzystały z możliwości

17 Szerzej zob. A. Rinke, Migration, Sicherheit, Wirtschaft. Afrika wird zu einer Priorität der deutschen und europäischen Politik, „Internationale Politik” 2016, Nr. 6, s. 8-16. 
wznowienia kontroli granicznej. Przywrócenie uregulowanych stosunków w tym aspekcie wiązano ze wzmocnieniem Frontexu.

Kluczową rolę w niemieckiej strategii antykryzysowej zajęła Turcja. Kontrowersyjność koncepcji delegowania ochrony zewnętrznej granicy UE na władze w Ankarze odzwierciedliły spory w ramach debaty ogólnej. Mimo świadomości kosztów finansowych i politycznych zwolennicy tej opcji byli przekonani o słuszności czy wręcz bezalternatywności zawarcia takiego porozumienia. W parze $\mathrm{z}$ tym stanowiskiem szło przekonanie o braku zdolności do zapewnienia ochrony granicy przez Grecję. Porozumienie z Turcją traktowane było jako model regulowania współpracy z sąsiadami UE w zakresie ochrony granicy morskiej. Niemcy zaangażowały się też w operację EUNAVFOR MED „Sophia” na Morzu Śródziemnym oraz w działania NATO na Morzu Egejskim.

Centralnym komponentem niemieckiego podejścia do kryzysu migracyjnego było dążenie do osiągnięcia rozwiązania europejskiego, uwzględniającego sprawiedliwy - jak twierdzono - mechanizm relokowania osób wnioskujących o azyl między państwa członkowskie. Obowiązkowy charakter mechanizmu dystrybucyjnego miał zapewniać udział wszystkich państw w przeciwdziałaniu przyczynom uchodźstwa i międzynarodowych konfliktów, a także zapewniać kooperatywną postawę państw zarządzających granicami zewnętrznymi UE.

Stosowane początkowo normatywne uzasadnienie dla obligatoryjnych kwot wzmocnione zostało z czasem argumentem uzależniającym od ich przyjęcia utrzymanie otwartych granic w UE. Angela Merkel wskazywała na analogiczny charakter deficytów konstrukcyjnych odnośnie do wspólnej waluty oraz $\mathrm{w}$ ramach drugiego filaru integracji europejskiej. Na etapie powoływania strefy Schengen nie osiągnięto - tak jak przy unii gospodarczej i walutowej - porozumienia politycznego w zakresie solidarności, kompetencji i relokacji na wypadek wystąpienia zwiększonej presji na granicach zewnętrznych. System wymaga zatem - jak przy euro - dopełnienia: „Dlatego solidarny podział uchodźców stosownie do siły gospodarczej i uwarunkowań, przy czym musi występować gotowość do stałego mechanizmu rozdziału, to nie jest jakaś drobnostka, tylko kwestia możliwości utrzymania strefy Schengen na dłuższą metę" (BT 2015-139, s. 13613). Domagano się zatem cięć funduszy strukturalnych wobec kontestujących centralistyczny model polityki azylowej państw Europy Środkowo-Wschodniej. 


\section{Podsumowanie}

Od 2008 r. tematyka kolejnych kryzysów odgrywała znaczącą rolę w debatach budżetowych toczonych w Bundestagu. Politycy partii koalicyjnych odwoływali się do niej w pierwszej kolejności w celu uzasadnienia podejmowanych działań, a następnie dla wzmacniania przekazu o pozytywnym bilansie rządów. Opozycja z kolei wskazywała na zaniechania bądź błędy w zarządzaniu kryzysowym.

Znamienne jest podkreślanie przez niemieckich polityków nadrzędnej wartości otwartości gospodarki i społeczeństwa w kryzysie finansowym i migracyjnym. Wymagało to także uznania związanego z tą otwartością ryzyka negatywnego oddziaływania zawirowań zewnętrznych na Niemcy.

Eksponowane miejsce zajmowały $\mathrm{w}$ debatach odwołania do koncepcji społecznej gospodarki rynkowej, z której wywodzono postulat aktywnej roli polityki w kryzysie. To w realizacji tego modelu upatrywano skutecznej ochrony przed zjawiskami kryzysowymi, a także zapewnienia zdolności sprawnej adaptacji do zmieniających się pod wpływem kryzysu uwarunkowań. Stosunkowo szybki powrót na ścieżkę wzrostu zinterpretowany został jako potwierdzenie skuteczności strategii zarządzania kryzysowego, a zarazem pomyślna weryfikacja modelu społecznej gospodarki rynkowej. Przyczyniło się to do utrwalenia przekonania o słuszności niemieckiego podejścia do polityki budżetowej i gospodarczej.

Zaangażowanie państwa w zarządzanie kryzysem finansowym było przedmiotem konsensu. Różnice stanowisk między reprezentowanymi w Bundestagu siłami politycznymi dotyczyły skali interwencji państwa, a przeważające były poglądy odwołujące się do założeń ordoliberalnych. Nadrzędnym celem niemieckiej polityki było zapewnienie konkurencyjności, która miała pozwolić na utrzymanie niemieckiego modelu gospodarczego opartego na eksporcie.

Stosunkowo sprawne opanowanie skutków kryzysu finansowego i jego następstw dla polityki realnej ugruntowało pozytywną ocenę własnych rozwiązań, które zaczęły być promowane jako modelowe na poziomie europejskim (np. hamulec długu publicznego - Schuldenbremse). Rosnącej roli Niemiec $\mathrm{w}$ formułowaniu odpowiedzi na kryzys w UE towarzyszyło ugruntowanie narracji o funkcji motoru wzrostu, a zarazem kotwicy stabilności dla wspólnej waluty. Jednocześnie jednak strategia komunikacyjna akcentująca lepszą kondycję Niemiec mogła się przyczyniać do desolidaryzacji wspólnoty $\mathrm{w}$ ramach strefy euro. 
Bodźcem, który zadecydował o przyjęciu aktywnego podejścia do zjawisk kryzysowych, był ich bezpośredni wpływ na Niemcy. Najpierw dotkliwe skutki załamania gospodarczego w następstwie światowego kryzysu finansowego, a po kilku latach kumulacja problemów logistycznych, społecznych, integracyjnych i bezpieczeństwa wewnętrznego na terenie Niemiec w związku z masową migracją, skutkowały doraźną mobilizacją zasobów państwa w celu łagodzenia objawów kryzysu. Ten sposób działania różnił się od reakcji na turbulencje w strefie euro, które początkowo nie były bezpośrednio odczuwane przez niemieckie społeczeństwo. W takich okolicznościach przeważyła postawa asekuracyjna, opierająca się presji szybkiego działania. Wśród niemieckich partii brakowało pewności co do właściwego doboru instrumentów, stanowisko rządu podlegało reaktywnym modyfikacjom, a inicjowanie kolejnych kroków przeciągano w czasie.

Przekonanie o stabilności niemieckiej gospodarki i sprawnym funkcjonowaniu państwa osłabiało zdolność rozpoznania negatywnego potencjału zjawisk kryzysowych na wczesnym etapie (zwłaszcza w wymiarze ekonomicznym) i przyczyniło się do opóźnienia odpowiedzi na wyzwania na poziomie krajowym, a także w ramach UE.

Kluczowym elementem dla odpowiedzi na kryzys było uznanie zaistnienia okoliczności o wyjątkowym charakterze. W przypadku kryzysu finansowego posłużyło to za uzasadnienie użycia przez państwo nadzwyczajnych środków, łącznie z odstąpieniem od strategicznego celu zrównoważenia budżetu. W odniesieniu do głęboko zintegrowanej strefy euro argument nadzwyczajnych okoliczności znajdował natomiast ograniczone zastosowanie. Nacisk na wymogi legitymizacyjne zawężał zdolność i gotowość Niemiec do sięgnięcia po instrumentarium proponowane w dyskusji o możliwościach przezwyciężenia kryzysu. Z kolei w kryzysie migracyjnym to inne państwa oponowały przeciwko niemieckim postulatom działań na poziomie UE, używając argumentów o zachowaniu władztwa przez państwa członkowskie.

\section{Bibliografia}

Alexander R., Angela Merkel i kryzys migracyjny. Dzień po dniu, Teologia Polityczna, Warszawa 2017.

Alexander R., Die Getriebenen. Merkel und die Flüchtlingspolitik: Report aus dem Innern der Macht, Siedler, München 2017.

Blume G., Brost M., Hildebrandt T., Hock A., Klormann S., Köckritz A., Krupa M., Lau M., Randow G. von, Theile M., Thumann M., Wefing H., Grenzöffnung für Flüchtlinge: Was geschah wirklich?, „Die Zeit”, 18 VIII 2016. 
Cziomer E., Rola Niemiec w kryzysie strefy Euro po 2009 roku, Krakowskie Towarzystwo Edukacyjne, Oficyna Wydawnicza AFM, Kraków 2013.

Giegerich B., Terhalle M., The Munich consensus and the purpose of German power, [w:] International security in the $21^{\text {st }}$ century. Germany's international responsibility, ed. J. Bindenagel, M. Herdegen, K. Kaiser, V\&R Unipress, Göttingen 2017.

Koszel B., Rola Niemiec w procesach decyzyjnych Unii Europejskiej w XXI wieku, Uniwersytet im. Adama Mickiewicza w Poznaniu, Wydawnictwo Naukowe Wydziału Nauk Politycznych i Dziennikarstwa, Poznań 2018

Maiziere T. de, Regieren. Innenansichten der Politik, Herder, Freiburg im Breisgau 2019.

Małachowski W., Skutki kryzysu i działania antykryzysowe $w$ gospodarce Niemiec, [w:] Państwa narodowe wobec kryzysu ekonomicznego, red. J. Osiński, Oficyna Wydawnicza Szkoły Głównej Handlowej, Warszawa 2010.

Pressekonferenz der Bundeskanzlerin und der Regierungschefinnen und Regierungschefs der Bundesländer, „Die Bundesregierung” [online], 18 VI 2015 [dostęp: 12 XI 2018], dostępny w internecie: <https://www.bundesregierung.de/breg-de/aktuelles/pressekonferenz-der-bundeskanzlerin-und-der-regierungschefinnen-und-regierungschefs-der-bundeslaender-846066>.

Reden auf der MSC 2014, „Munich Security Conference” [online, dostęp: 12 XI 2019], dostępny w internecie: $<$ https://www.securityconference.de/aktivitaeten/munich-security-conference/ munich-security-conference/msc-2014/reden/>.

Rinke A., Deutschlands neue Nachbarn. Die Bundesregierung weitet ihren Blick auf den Krisenbogen um die EU, „Internationale Politik” 2017, Nr. 4.

Rinke A., Migration, Sicherheit, Wirtschaft. Afrika wird zu einer Priorität der deutschen und europäischen Politik, „Internationale Politik” 2016, Nr. 6.

Schwarzer D., Germany's role and strategy in the euro area-determining factors and scenarios, „The Polish Quarterly of International Affairs” 2013, No. 2.

Steinbrück P., Unterm Strich, Hoffmann und Campe, München 2011. 